\title{
A Re-Assessment of the Role of the Financial Sector in Driving Economic Growth: Recent Evidence from Cross Country Data
}

\author{
Sanjay Sehgal ${ }^{1}$, Wasim Ahmad $^{1} \&$ Florent Deisting ${ }^{2}$ \\ ${ }^{1}$ Department of Financial Studies, University of Delhi, South Campus, Benito Juarez Road, New Delhi, India \\ ${ }^{2}$ Groupe ESC Pau - France, rue Saint-John Perse - BP 7512-64075, France \\ Correspondence: Sanjay Sehgal, Department of Financial Studies, University of Delhi, South Campus, Benito \\ Juarez Road, New Delhi, 110 021, India. Tel: 91-989-119-9840. E-mail: sanjayfin15@gmail.com
}

Received: September 10, 2012

Accepted: November 15, 2012 Online Published: December 10, 2012

doi:10.5539/ijef.v5n1p133

URL: http://dx.doi.org/10.5539/ijef.v5n1p133

\begin{abstract}
In this study, we evaluate the empirical relationship between financial development and economic growth for 75 countries classified into different income groups. The study covers the sample period of 1990-2009. The empirical results suggest that there is a long-run equilibrium relationship between financial development and economic growth. The estimated results of FMOLS and MWALD Granger causality tests indicate that banks play a dominant role in promoting economic growth across all income groups. Savings significantly drive growth for low and middle income groups. Economic growth propels stock market development for low income group, stock market and economic growth are reinforcing for middle income group. While, stock market emerges as an important driver of economic growth for high income countries. Our findings are consistent with prior research and are relevant for academician, policy makers as well as financial institutions and market players.
\end{abstract}

Keywords: panel cointegration, causality, economic growth, financial development, policy intervention JEL: E02, E44, F23, O16

\section{Introduction}

The role of financial sector in accelerating the economic growth has long been an issue of debate among researchers and policy makers. Even after decades, empirical research has not yielded a consensus on this issue in both developed and developing economies. More recently, the subject has garnered attention due to its alleged role in recent global economic crisis and its subsequent contagion effects on Euro-zone countries. The impact of financial sector turbulence has been severe and it has impacted the global economy considerably. Taking the above discussion as starting point, the present study attempts to examine the relationship between financial development and economic growth across income groups using panel data of 75 countries, categorised further into different income based sub-groups. By doing so, it will be helpful for the researchers and regulators in undertaking the co-ordinated policy measures to revive the distressed economies and also to figure out the potential financial development channel for not only mature economies but also for emerging markets. Many studies have emphasized on the constructive role of the financial sector in mobilizing and intermediating saving, and ensuring that these resources are allocated efficiently to productive sectors (Ang, 2008). However, literature suggests that there is disagreement among the academicians on the role of financial sector in driving economic growth. Like for example, studies of Harris (1997) and Deidda (2006) suggest that the relationship between financial development and economic growth is strongly positive at relatively high levels of per-capita income and weak/negative or insignificant at relatively low levels of per-capita income which ultimately rests upon the efficiency of financial intermediaries and other related conditions in the economy Cameron, Olga, Hugh \& Richard (1967), McKinnon (1973), King and Levine (1993a). On the contrary, few studies have also highlighted its negative effects and argued that financial development can hurt economic growth particularly when enhancing resource allocation may result in low savings rate. There is still evidence of widespread scepticism on the role of financial intermediaries' especially financial market. ${ }^{1}$ Stiglitz (1994) argue that stock market will not produce the same improvement in resource allocation and corporate governance as banks because it produces too much speculative activities Keynes (1936), Kindleberger (1978), Singh (1997). 
Beginning with the seminal cross-country analysis of King and Levine (1993a), several empirical studies by combining the endogenous growth theories and market microstructure of financial system have provided empirical support for the leading view that financial development promotes economic growth (Rajan \& Zingales, 1998; Rousseaua \& Wachtel, 2000; Levine, Loayza \& Thorsten, 2000). On the other hand, some studies find no significant causal relationship between financial development and economic growth (Khan \& Senhadji, 2003; Hong \& Thai, 2004; Al-Awad \& Nasri, 2005; Hassan, Sanchez \& Yu, 2011). Thus, the empirical evidence on the subject can at best be described as mixed. More importantly, most of the cross country studies are sensitive to the sample countries, estimation methods, data frequency and functional forms of the relationship and proxy measures chosen. All of which raised doubts about the reliability of cross-country regression analysis. In order to avoid such difficulty, panel data estimation seems more appropriate because it minimizes the errors associated with time-series and cross-sectional variations in the data and avoids time series specification biases related with sample size and subsequent inclusion of variables which helps in obtaining valid inferences by taking into account fixed effects. ${ }^{2}$

This study attempts to examine the relationship between financial development and economic growth across income groups using panel data. The study has two major objectives: First, to examine the long-run relationship between financial development and economic growth across income groups using dynamic panel approach and multivariate time-series analysis. In so doing, the magnitude of the estimated long-run elasticities with respect to the measures of banking and stock market developments is likely to shed light upon the relative importance for economic growth. Second, to investigate the causal flows, i.e., between economic growth and financial development on one hand and economic growth and macroeconomic factors on the other.

This study uses the balanced panel data of 75 countries, classified further into four income groups, based on the World Bank criteria. The study incorporates banking and stock market indicators as well as level of gross domestic savings in order to substantiate the role of financial system in driving economic growth across countries ( (Levine \& Zervos, 1997; Arestis, Demetriades \& Luintel, 2001). The study variables considered in this study are in agreement with neo-classical growth framework and with the studies of King and Levine, (1993a), Levine et al.(2000), Hassan et al. (2011) among others.

The study is organised into six sections including the present one. Section 2 provides a literature review. Section 3 describes the data and the proxy measures of financial development as well as real sector and economic growth Section 4 describes the balanced panel estimations and multivariate time-series methodologies applied in the paper. Section 5 analyses the empirical results, while the last section contains conclusion and policy suggestions.

\section{Literature Review}

In recent decades, a pool of literature has provided the evidence of relationship between financial development and economic growth. During 1960s and 1970s, due to pioneering contributions of (Goldsmith, 1969; McKinnon, 1973) the relationship between economic growth and financial development has remained an important issue of debate among academics and policymakers. During 1990s, a large number of studies emphasized particularly on the role of the financial intermediaries in mobilizing savings, allocation of scarce resources, diversification of risks and contribution to economic growth (Gregorio and Guidotti, 1995) majority of these studies have concentrated only on the role of banking sector in financial development. Like for example, King and Levine, (1993a, b) used the banking development indicators such as the total liquid liabilities of financial intermediaries (e.g., M3) divided by Gross Domestic Product (GDP), which has later been augmented by the studies of Levine and Zervos (1998) and Beck, Levine, and Loayza (2000) by incorporation of new variable viz., credit to private firms. Very limited studies have analysed the stock market development due to paucity of data. The new growth theories argue that financial intermediaries and markets appear endogenously in response to market incompleteness and, hence, contribute to long-term growth. Financial institutions and markets, which arise endogenously to mitigate the effects of information and transaction cost frictions, influences decisions to invest in productivity-enhancing activities through evaluating prospective entrepreneurs and funding the most promising ones. The underlying assumption is that financial intermediaries can provide these evaluation and monitoring services more efficiently than individuals. Levine and Zervos 1998) conducted a study by estimating cross country regressions for a number of countries for the period 1976-1993, and concluded that equity market is positively correlated with measures of real activity and that the association is particularly strong for developing countries. They also provided the evidence of how stock market provides different financial services from banks and emphasized on the role of stock market in fostering the economic growth. Atje and Jovanovic (1993) using a similar approach, also found a significant correlation between economic growth and the value of stock market trades relative to GDP for forty countries over the period 1980-88. However, Harris (1997) showed that this relationship is weak. Re-estimating the same model for forty-nine countries over the period 1980-91, but 
using current investment rather than lagged, and utilizing two-stage least squares, he demonstrated that in the case of the full sample (which includes both developed and developing countries), and of the sub-sample of developing countries, the stock market variable does not offer much incremental explanatory power. In the sub-sample of developed countries, although the level of stock market activity has some explanatory power, its statistical significance is weak. But the recent literature based on the application of time-series and panel data regressions provide evidence of causal relationship between financial development and economic growth by using various proxies of financial development (including banks and stock market). So far as many studies have analysed the direction of causality after establishing the long-run relationship. Some authors have theoretically and empirically shown that there is causal direction from financial development to economic growth (King \& Levine, 1993a; Levine et al. 2000; Christopoulos \& Tsionas, 2004). Other studies have supported the argument by establishing the causal direction running from economic growth to financial development (Gurley \& Shaw, 1967; Goldsmith, 1969).

Many significant studies have also provided the evidence of bilateral causal direction i.e., that is financial development and economic growth reinforce each other. Patrick and Yung (1994) postulated the different stages of development hypothesis. At the early stage, causality runs from finance to growth, but at later stage causality runs from growth to finance. In the early stage of economic development, finance causes growth by inducing real per capita capital formation. Later on, the economy is in the growth stage and there will be increasing demand for financial services, which induces an expansion in the financial sector as well as the real sector. This implies causality from growth to finance. Blackburn and Hung (1998) also established a positive two-way causal relationship between growth and financial development. According to their analysis, private informed agents obtain external financing for their projects through incentive-compatible loan contracts, which are enforced through costly monitoring active ties that lenders may delegate to financial intermediaries. More recently, Khan (2001) also established a positive two-way causality between finance and growth. He postulated that when borrowing is limited, producers with access to loans from financial intermediaries obtain higher returns, which creates an incentive for others to undertake the technology necessary to access investment loans, which in turn reduces financing costs and increases economic growth. Levine (2005) surveyed a large amount of empirical research that deals with the relationship between the financial sector and long-run growth. (Levine, 1997) argued that financial systems can accomplish five functions to ameliorate information and transaction frictions and contribute to long-run growth. These functions are: facilitating risk amelioration, acquiring information about investments and allocating resources, monitoring managers and exerting corporate control, mobilizing savings, and facilitating exchange. These functions support investment and, hence, higher economic growth. The results in the literature, however, are contradictory. On one hand, cross-country and panel data studies find a positive effect of financial depth on economic growth after accounting for other determinants of growth and potential biases induced by simultaneity, omitted variables or country-specific effects (Levine, 2005) suggesting that the causality runs from finance to growth (Khan \& Senhadji, 2003; Levine et al.2000). Furthermore, Claessens and Laeven (2005) related banking competition and industrial growth and found that the higher the competition among banks, the faster the growth of finance-dependent industries, suggesting also that higher financial development precedes economic growth.

On the other hand, Demetriades and Hussein (1996) and Shan, Morris and Sun (2001), using time-series techniques, found that the causality is bi-directional for the majority of countries in their sample. Furthermore, Luintel and Khan (1999) using a sample of 10 developing countries, concluded that the causality between financial development and output growth is bi-directional for the 10 countries they studied. Calderon and Liu ( 2003) using a sample of 109 developing and developed countries, found evidence that financial development generally leads to economic growth for developed countries, but that the Granger causality is two-way for developing countries. Since financial development is not easily measurable, papers attempting to study the link between financial deepening and growth have chosen a number of proxy measures and subsequently have come up with different results (King \& Levine, 1993a; Khan \& Senhadji, 2003; Chuah \& Thai, 2004; Al-Awad \& Harb, 2005, among others). However, the general consensus of these studies is that there is a positive correlation between financial development and economic growth.

Deidda (2006) developed a theoretical framework of financial and economic development which assumes the consumption of real resources by the financial sector. According to him, financial development occurs endogenously as the economy reaches a critical threshold of economic development. He argued that a role of financial intermediary helps in channelling the scare resources to productive investments which is not feasible in financial autarky. According to him whenever the technology financed by intermediaries is more capital-intensive than that operated in financial autarky, the growth effect of financial development is ambiguous. 
Cole, Moshirian and $\mathrm{Wu}(2008)$ in their study analysed the relationship between banking industry and stock returns and future economic growth. Using dynamic panel data techniques on 18 developed and 18 emerging markets, they found a positive and significant relationship between bank stock returns and future GDP growth. Their proxy variables of financial development were stock prices and market capitalizations of individual banks and the market price index for each country. However, given the vast amount of literature available on this subject Ang (2008) provides a comprehensive survey of literature on relationship between financial development and economic growth. ${ }^{3}$ Caporale, Christophe, Robert and Anamaria (2009) in their study tried to find out the relationship between financial development and economic growth for ten EU member countries by estimating dynamic panel model over the period 1994-2007. Their study though focussed only one the role of banking sector concluded that stock and credit markets are still underdeveloped in these economies, and that their contribution to economic growth is limited owing to a lack of financial depth. Cooray (2010) tried to augment the Mankiw, Romer and Weil (1992) model with a variable for the stock market. The study finds strong support for the stock market augmented model for a cross section of 35 developing economies. The variables used in the study were GDP per capita, Share of investment to GDP, annual average growth of labour force, average population growth rate, net secondary enrolment ratios, net primary enrolment ratios and stock market variables. However, Wu, Han and Su-Yin (2010) provided an evidence of a long-run equilibrium relationship among banking development, stock market development and economic development, and stock market capitalization and liquidity have positive long-run effects on economic development in 13 countries in European Union over the period 1975-2005. Iyare and Moore (2011) carried out a study to investigate the causal relationship between financial development and economic growth for four small open economies viz., Barbados, Jamaica, Singapore, and Trinidad and Tobago. The study results concluded that growth tends to lead financial development in Singapore and Jamaica, financial development leads growth in Trinidad and Tobago and there is a bidirectional link in Barbados.

Hassan, Sanchez and Yu (2011) carried out a study on the role of financial development in low and middle-income countries classified by geographic regions. Using panel regressions, causality and variance decomposition tests, they inferred that there is positive relationship between financial development and economic growth. They established two-way causality in case of two poorest regions. Finally their study concluded that a well-functioning financial system is a necessary but not sufficient condition to achieve steady economic growth in developing countries. In sum, the empirical evidence on the issue of causal relationship is mixed. The relationship between financial development and economic growth seems to vary across economic settings, time frames and empirical findings which are sensitive to the choice of estimation methods. Hence, the debate on this pertinent issue remains unresolved and warrants further research.

\section{Data and Proxy Measures}

\subsection{Structuring the Panel Dataset}

The sample period of panel data used in the study is 1990-2009, covering 75 countries, classified further into four income groups based on World Bank classification criteria. ${ }^{4}$ Sample countries get reduced because of non-availability/non-existence of stock market data such as market capitalization to GDP ratio. This was required to create balanced panel for further estimation. Due to lack of data on stock market variables in low income group only three economies (viz., Bangladesh, Kenya and Zimbabwe) have been considered in the analysis and in order to avoid the estimation issues, the low income countries are merged with lower middle income group (hereafter, Low income group shall comprise of low as well as lower middle income countries). The number of sample countries in each group are as follows: Low income group (13), Middle income group (this includes only upper middle income countries, 24), High income-OECD (31) and High Income Non-OECD (7), making a total of 75 countries in the sample. ${ }^{5}$ It may be noted that the panel dataset is constructed separately for each group in the study. The aggregate sample estimation is not performed. This is mainly to obtain the inference for each income group as the degree of financial development may have different impact on economic growth for different economic settings. This dataset allows us to analyse the various panel data models such as panel cointegration developed by Pedroni $(1999,2001)$ and Fully Modified Ordinary Least Squares (FMOLS) in order to measure the magnitude of long run relationship between financial development and economic growth. The sufficient number of data points also permits us to effectively estimate the dynamic panel estimation with sufficient degrees of freedom and analyse various multivariate time-series models within each income group. The main reason of choosing countries based on income group is to have an overview about the direction of level of financial development across income groups.

Apart from culture and geography, income is still regarded as one of the most important factors of fostering the level of financial development across countries. At the early stage, at low levels of per-capita income finance 
leads to growth by inducing economic growth. Later on, the economy is in the growth stage and there will be increasing demand for financial services consequent to rise in income, which induces an expansion in the financial sector as well as the real sector (Deidda, 2006). This phenomenon is widely acknowledged and therefore, instead of constructing geography wise data we have formed a panel data based on income. Besides this, as Hassan et al. (2011) raise that geographic classification is assigned only to the low and middle income group by World Bank. Therefore, classification of countries based on income seems more appropriate than based on geographic regions.

\subsection{Proxy Measures for Financial Development and Economic Growth}

Numerous studies have used various indicators to measure the economic growth and level of financial development starting from banking indicators such as domestic credit to the private sector as ratio to GDP (DCPBS), Broad money (M3)/Narrow money (M1) supply as percentage of GDP (BM), domestic credit provided by banking sector as percentage of GDP (DMCPS). Very few studies have used the indicators of stock market development such as market capitalization as percentage of GDP (MARCAP), value traded as percentage of GDP (STRADED), turnover ratios, and number of listed companies (COMP) to study the level of financial development (Harris, 1997; Levine and Zervos, 1998; Enisan \& Olufisayo, 2009). For banking and stock market development, we employ all the above mentioned variables except turnover ratios due to missing observations for large number of countries and instead we have considered number of listed companies to capture the level of financial development in the sample countries. The banking and stock market variables have been used to construct Banking Development Index (BDI) and Stock Market Development Index (SMDI) using principle component analysis. ${ }^{6}$ The index construction exercise has been performed in case of income panels for which the banking proxy and stock market proxy groups exhibit statistically significant correlation within each group. The BDI is constructed for all income groups as there were significant correlations between banking proxies for all these groups. However, SMDI index construction exercise has been performed only for stock market proxies in case of high income-OECD and Non-OECD countries given the high correlation among stock market proxies. In the absence of any significant correlations, stock market development has been proxied by value traded to GDP ratio for low and middle income countries. The choice of stock market proxy is based on the premise that Foreign Institutional Investors (FIIs) play an important role in stock market activity for these countries and their actions, along with those of domestic investors, can be better reflected by observing value traded to GDP. Market cap to GDP ratio for these countries are highly volatile given the speculative pressure in these markets, while number of companies (number of listed companies) don't fairly represent market performance owing to the fact that a large number of these companies may be thinly traded and hence the company count doesnot reflect the breadth and depth of these market. Except number of companies listed, all other variables considered in this study are in agreement with earlier studies of (Levine et al. 2000; Levine \& Zervos, 1998; Arestis et al. 2001; Wu, Han \& Su-Yin, 2010; Hassan et al. 2011) provide justification of using these banking as well as stock market indicators. A high ratio of domestic credit to GDP indicates not only a higher level of domestic investment, but also higher development of the financial system. Financial systems that allocate more credit to the private sector are more likely to be engaged in researching borrower firms, exerting corporate control, providing risk management control, facilitating transactions, and mobilizing savings (Levine, 2005), that requires a higher degree of financial development.

Besides this, the present study also uses the broadest definition of money (M3) - as a proportion of GDP - to measure the liquid liabilities of the banking system in the economy. We used M3 as a financial depth indicator because the other two monetary aggregates (M2 or M1) may be a poor proxy in economies with underdeveloped financial systems because they are more related to the ability of the financial system to provide transaction services than to the ability to channel funds from savers to borrowers (Khan and Senhadji, 2003). A higher liquidity ratio means higher intensity in the banking system. The assumption here is that the size of the financial sector is positively associated with financial services (King and Levine, 1993b). It may here again be noted that M1 as percentage of GDP is considered for few countries whose data of M3 is missing. The gross domestic savings as percentage of GDP (GDS), (Hassan et al., 2011) conclude that the steady state growth rate depends positively on the percentage of savings diverted to investment, stressing that converting savings to investment is one channel through which financial deepening affects growth. In other words, financial development is expected to benefit from higher GDS and, consequently, higher volume of investment. In most developing countries, financial repression and credit controls lead to negative real interest rates that reduce the incentives to save. According to this view, a higher GDS resulting from a positive real interest rate stimulates investment and growth (McKinnon, 1973). 
The study also employs three macroeconomic variables which may possibly bear the relationship with economic growth: Inflation, Trade and FDI. Trade and FDI as percentage of GDP ensure the external orientation of an economy. Inflation is an important policy variable that impacts economic growth. Especially in low and middle income countries, it remains a major problem to control rising inflation. Political regimes in these economies handle high inflation by tightening monetary policy, leading to slower capital formation and retardation of economic growth. Most economies are pursuing aggressively the policies of financial liberalization along with opening of trade, the role of FDI and trade expansion could be greatly acknowledged in this regard. However, the role of FDI is expected to be higher in case of low and middle income countries which are undergoing economic transition and hence attract higher external investments. Trade as percentage of GDP on the other hand shows stronger link with economic growth and plays a more critical for high income countries given the large share they enjoy in global trade. Finally, we use real GDP per capita to proxy the level of economic growth (log level of GDP per capita), labelled as LGDPPC (see Gries, Kraft \& Meierrieks, 2009; Iyare \& Moore, 2011). All the data is downloaded from World Bank's World Development Indicators (WDI), 2011 database. In case of missing values we also explored the respective central banks of countries and also retrieved the data from OECD database.

\section{Methodology}

Following the empirical literature, we specify the model as follows:

$$
\begin{aligned}
& L G D P P C=\beta_{0}+\beta_{1} L B D I_{i t}+\beta_{2} S T R A D E D_{i t}+\beta_{3} G D S_{i t}+\beta_{4} I N F_{i t}+\beta_{5} T R A D E_{i t}+\beta_{6} F D I_{i t}+\mu_{i t} \\
& L G D P P C=\beta_{0}+\beta_{1} L B D I_{i t}+\beta_{2} L S M D I_{i t}+\beta_{3} G D S_{i t}+\beta_{4} I N F_{i t}+\beta_{5} T R A D E_{i t}+\beta_{6} F D I_{i t}+\mu_{i t}
\end{aligned}
$$

Where $i$ in equation (1) denotes income group 1 and 2 and $i$ in equation (2) denotes income group 3 and 4 , $t=1 \ldots . . T$ denotes the time period, and $\mu_{i t}$ is assumed to be serially uncorrelated error term. The variables LGDPPC, LBDI, LSMDI, STRADED, GDS, INF, TRADE and FDI represent the natural logarithm of real GDP per capita, Banking development index and Stock market development index, Stock traded, Inflation, Trade and FDI, respectively. Next, we turn to estimate panel unit root tests viz., Levin, Lin and Chu (LLC), Breitung, Im, Pesaran and Shin (IPS), a Fisher-type test using Augmented Dickey-Fuller (ADF) and Phillips-Perron (PP) tests. Both LLC and Breitung tests assume that there is a common unit root process across the cross-sections. For these tests, the null hypothesis is that there is a unit root, while the alternative hypothesis is that there is no unit root. After the test of stationarity, we estimate Pedroni $(1999,2001)$ heterogenous panel cointegration test which allows for cross section interdependence with different individual effects. The model is estimated as follows:

$$
\begin{gathered}
L G D P P C=\alpha_{i}+\delta_{i} t+\gamma_{1 i} L B D I_{i t}+\gamma_{2 i} S T R A D E D_{i t}+\gamma_{3 i} G D S_{i t}+\gamma_{4 i} I N F_{i t}+\gamma_{5 i} T R A D E_{i t}+\gamma_{6 i} F D I_{i t}+\varepsilon_{i t} \\
L G D P P C=\alpha_{i}+\delta_{i} t+\gamma_{1 i} L B D I_{i t}+\gamma_{2 i} L S M D I_{i t}+\gamma_{3 i} G D S_{i t}+\gamma_{4 i} I N F_{i t}+\gamma_{5 i} T R A D E_{i t}+\gamma_{6 i} F D I_{i t}+\varepsilon_{i t}
\end{gathered}
$$

Where $\mathrm{i}=1 \ldots . \mathrm{N}$ for each country in the panel and $\mathrm{t}=1 \ldots \ldots . \mathrm{T}$ refers to the time period. The parameters $\alpha_{i}$ and $\delta_{i}$ allow for the possibility of country-specific fixed effects and deterministic trends, respectively. $\varepsilon_{i t}$ denotes the estimated residuals which represent deviations from the long-run relationship. All variables are expressed either in natural logarithms or percentage of GDP so that $\gamma$ 's parameters of the model can be interpreted as elasticities. To test for the null hypothesis of no cointegration $\rho_{i}=1$, the following unit root test is conducted to the residuals as follows:

$$
\varepsilon_{i t}=\rho_{i} \varepsilon_{i t-1}+\omega_{i t}
$$

Pedroni (1999 \& 2004) proposes two tests for cointegration. The panel tests are based on the within dimension approach which includes four statistics: panel v, panel $\rho$, panel PP and panel ADF statistics. These statistics essentially pool the autoregressive coefficients across different countries for the unit root tests on the estimated residuals. These statistics take into account common time factors and heterogeneity across countries. The group tests are based on the between dimension approach which includes three statistics: group $\rho$, group PP and group ADF statistics. These statistics are based on averages of the individual autoregressive coefficients associated with unit root tests of the residual of each country in the panel data set. The seven statistics for each panel data set reject the null hypothesis of no cointegration at the given level of significance.

Given the presence of cointegration, we estimate the long-run relationship between economic growth and financial and other macroeconomic policy variables. The OLS estimator is a biased and inconsistent estimator when applied to co-integrated panels. Therefore, we estimate the long-run relationship using FMOLS approach 
suggested by (Pedroni, 2001). The FMOLS approach not only generates consistent estimates in small samples but also controls for the likely endogeneity of the regressors and serial correlation. The panel FMOLS estimator for the co-efficient $\beta$ is given as follows:

$$
\hat{\beta}_{N T}=N^{-1} \sum_{i=1}^{N}\left(\sum_{i=1}^{T}\left(X_{i t}-\bar{X}_{i}\right)^{2}\right)^{-1}\left(\sum_{i=1}^{n}\left(X_{i t}-\bar{X}_{i}\right) Y_{i t}^{*}-T \hat{\tau}\right)
$$

Where $Y_{i t}^{*}=\left(Y_{i t}-\bar{Y}_{i}\right)-\frac{\hat{L_{21 i}}}{\hat{L_{22 i}}} \Delta X_{i t}$ and $\hat{\tau}=\hat{\Gamma}_{21 i}+\hat{\Omega}_{21 i}-\frac{\hat{L_{21 i}}}{\hat{L_{22 i}}}\left(\hat{L_{22 i}}+\hat{\Omega_{22 i}}\right)$. The associated $t$-statistics follow normal distribution. The results of panel FMOLS are reported in Table 3.

After this, we move to test the Toda and Yamamoto's (1995) version of Granger causality. It is well known that F-test of causality in VAR is not valid in the presence of non-stationary series. Toda and Yamamoto however propose a procedure that is robust enough to address the cointegration features of the series (e.g., it is valid without regard to cointegration process to the cointegration process of the variables). The procedure basically involves four steps. First, find the highest order of integration in the variables $\left(\mathrm{d}_{\max }\right)$. Second, find the optimal number of lag for the VAR model (m). Third, overfit (on purpose) VAR regression by estimating $\left(\mathrm{m}+\mathrm{d}_{\max }\right)^{\text {th }}$ order using seemingly unrelated regression (SUR). We used SUR because the WALD test gains efficiency if the VAR is estimated using SUR (Pittis, 1999). Finally, test the null hypothesis of no granger causality using the Modified Wald (MWALD) test, which follows a standard $\chi^{2}$-satistics with $m$ degrees of freedom. A critical step of the Toda and Yamamoto (1995) procedure is the number of lags in the VAR. Using Schwartz Bayesian criterion, the optimal number of lags is two in case of low and Non-OECD income groups and three in case of middle and high income-OECD countries lags. Finally, we also apply the VAR based variance decomposition which is used to determine how much of the k-step ahead forecast error variance of a given variable is explained by innovations to each explanatory variable. In practice, it is usually observed that own series shocks most of the (forecast) error variance of the series are present in the VAR.

\section{Empirical Results}

We begin the empirical analysis with summary statistics (see Table 1) of all study variables for different income groups. The mean change in banking and stock market variables viz., Broad money (BM), Domestic Credit Provided by Banking Sector (DCPBS) as percentage of GDP, Domestic Credit Provided to Private Sector (DMCPS) as percentage of GDP, Market cap as percentage of GDP and STRADED, is more pronounced from middle to high income countries than from low to middle income countries. Mean GDS increases from $16 \%$ to $24 \%$ from low to middle income countries and then stabilises further high income and non-OECD countries.

We then move to the unit root tests, by and large the, results of panel uni root tests demonstrate that at $5 \%$ level of significance all study variables viz., LGDPPC, LBDI, STRADED, LSMDI, GDS, INF, FDI and TRADE are having unit root at level and attain stationarity after first difference. ${ }^{7}$ The panel tests include a constant and a heterogenous time trend in their specifications. Since LSMDI variable is included only in case of High income (OECD) and Non-OECD groups and hence the unit root test results of LSMDI variable is replaced with STRADED in rest of the two groups. 
Table 1. Summary of statistics by income groups (1990-2009)

\begin{tabular}{|c|c|c|c|c|c|c|c|c|c|c|c|}
\hline & \multicolumn{7}{|c|}{ Financial Sector Development } & \multicolumn{4}{|c|}{ Real Sector Development } \\
\hline & \multicolumn{3}{|c|}{ Stock Market Development } & \multicolumn{4}{|c|}{ Banking Development } & & \multirow[b]{2}{*}{ FDI } & \multirow[b]{2}{*}{ TRADE } \\
\hline & MARCAP & COMP & STRADED & $\mathbf{B M}$ & DCPBS & DMCPS & GDS & (US \$) & INF & & \\
\hline \multicolumn{12}{|c|}{ Low Income $(n=13)$} \\
\hline Mean & 28.7 & 584 & 10.77 & 44.5 & 49.32 & 30.61 & 15.9 & 2,191 & 33 & 1.73 & 59.7 \\
\hline Median & 142.77 & 220 & 183.66 & 45.4 & 42.71 & 46.9 & 50.8 & 51 & 420.6 & 118.4 & 36.02 \\
\hline Min & 0.4 & 2 & 0.01 & 12.2 & 4.91 & 3.66 & -25.9 & 283 & 0.6 & -2.76 & 15.68 \\
\hline Max & 510.4 & 5,999 & 128.65 & 120.5 & 165.9 & 104.47 & 34.1 & 5,274 & $1,096.70$ & 12.2 & 116.1 \\
\hline \multicolumn{12}{|c|}{ Middle income ( $(n=24)$} \\
\hline Mean & 42.6 & 315 & 15.2 & 50.5 & 58.9 & 48.8 & 24.1 & 7,817 & 60.6 & 3 & 76.7 \\
\hline Median & 22.5 & 138 & 3 & 37.2 & 48.4 & 31.3 & 22.3 & 7,559 & 7.9 & 2.6 & 64.3 \\
\hline Min & 0 & 3 & 0 & 6.2 & -73 & 7.2 & -10 & 1,101 & -1.4 & -6.9 & 13.8 \\
\hline Max & 328.9 & 5,825 & 229.7 & 159.4 & 195.3 & 165.7 & 52 & 14,767 & $7,481.70$ & 22.7 & 220.4 \\
\hline \multicolumn{12}{|c|}{ High Income-OECD $(n=31)$} \\
\hline Mean & 62.4 & 755 & 49.8 & 114 & 111 & 94.9 & 24 & 26,611 & 6 & 11.1 & 85.2 \\
\hline Median & 47 & 222 & 25.3 & 76.8 & 102.3 & 87.5 & 23.7 & 26,339 & 2.7 & 2.1 & 71.6 \\
\hline Min & 0.2 & 9 & 0 & 18.3 & 0.3 & 0.3 & 5.6 & 7,285 & -4.5 & -15 & 16 \\
\hline Max & 323.7 & 8,851 & 409.5 & 636.5 & 328.4 & 319.5 & 53.2 & 74,114 & 555.4 & 564.9 & 326.8 \\
\hline \multicolumn{12}{|c|}{ High Income Non-OECD $(n=7)$} \\
\hline Mean & 112.5 & 206 & 58 & 96.7 & 84.6 & 84.6 & 31.5 & 22,915 & 3 & 6.9 & 167 \\
\hline Median & 60.5 & 77 & 7.7 & 72.8 & 65.7 & 57.1 & 30.7 & 20,180 & 2.3 & 5.7 & 104.3 \\
\hline Min & 8.5 & 14 & 0.1 & 24.9 & -4 & 14.9 & 11.9 & 10,499 & -4 & -1.3 & 56.5 \\
\hline Max & 1095 & 1,308 & 755.1 & 321.6 & 302.9 & 269.7 & 55.6 & 49,877 & 12.1 & 36.6 & 438.1 \\
\hline
\end{tabular}

Note: Total number of countries in the sample $(\mathrm{N}=75)$.

\subsection{Panel Cointegration Tests Results}

The panel cointegration results (see Table 2) show that the model viz., LGDPPC, LBDI, STRADED, GDS, INF, FDI and TRADE, used for low income and middle income groups, except for the panel variance (only in case of middle income group), panel $\rho$-statistic, group $\rho$ - statistics, and all other statistics are statistically significant. Hence, we reject the null of no cointegration. Similarly, the panel cointegration model of high income-OECD and non-OECD viz., LGDPPC, LBDI, LSMDI, GDS, INF, FDI and TRADE, all cointegration coefficients are significant except panel $\rho$-statistic, panel ADF-statistics (only in case of Non-OECD) and the group $\rho$-statistics, significantly rejecting the null of no-cointegration. Therefore, it can be inferred that there is a long-run relationship among study variables and across all income groups.

Table 2. Pedroni Cointegration test results

\begin{tabular}{|c|c|c|c|c|c|c|c|c|}
\hline & \multicolumn{2}{|c|}{ Low income } & \multicolumn{2}{|c|}{ Middle income } & \multicolumn{2}{|c|}{$\begin{array}{l}\text { High Income } \\
\text { (OECD) }\end{array}$} & \multicolumn{2}{|l|}{ High income non-OECD } \\
\hline & Statistic & Prob. & $\underline{\text { Statistic }}$ & Prob. & Statistic & Prob. & Statistic & Prob. \\
\hline \multicolumn{9}{|l|}{ Within dimension } \\
\hline Panel variance & $1.6562 *$ & 0.0488 & -2.8746 & 0.9980 & $11.1350^{*}$ & 0.0000 & $5.5282 *$ & 0.0000 \\
\hline Panel $\rho$-Statistic & 3.5486 & 0.9998 & 4.8094 & 1.0000 & 4.2350 & 1.0000 & 2.7231 & 0.9982 \\
\hline Panel PP-Statistic & $-4.0772 *$ & 0.0000 & $-8.0916^{*}$ & 0.0000 & $-6.8613^{*}$ & 0.0000 & $-4.4953^{*}$ & 0.0000 \\
\hline Panel ADF-Statistic & $-5.5244 *$ & 0.0000 & $-6.0654 *$ & 0.0000 & $-7.0415^{*}$ & 0.0000 & -0.2991 & 0.3303 \\
\hline \multicolumn{9}{|l|}{ Between dimension } \\
\hline $\begin{array}{lll}\text { Group } \rho & \text {-Statistic }\end{array}$ & 5.6224 & 1.0000 & 6.8724 & 1.0000 & 7.5739 & 1.0000 & 3.7782 & 0.9999 \\
\hline Group PP-Statistic & $-6.3810^{*}$ & 0.0000 & $-7.1657^{*}$ & 0.0000 & $-3.9858^{*}$ & 0.0000 & $-5.1735^{*}$ & 0.0000 \\
\hline Group ADF-Statistic & $-1.9247^{*}$ & 0.0271 & $-2.9020^{*}$ & 0.0019 & $-2.7859^{*}$ & 0.0027 & 0.5873 & 0.7215 \\
\hline
\end{tabular}

Note:* indicates the rejection of the null hypothesis at $5 \%$ and $10 \%$ level of significance, respectively. The lag lengths are selected using AIC. 


\subsection{Fully Modified OLS (FMOLS) Test Results}

After establishing the cointegration relationship, the fully modified OLS (FMOLS) technique for heterogenous co-integrated panels is estimated to determine the long-run equilibrium relationship (Pedroni, 2000). Table 3 reports the FMOLS results. For low income countries, all the coefficients are statistically significant at $5 \%$ level of significance with acceptable signs (with the exception of TRADE). The results indicate that a $1 \%$ increase in banking index increases economic growth (LGDPPC) by more than $0.19 \%$; a $1 \%$ increase in gross domestic savings increases real GDP by $0.12 \%$; and, a $1 \%$ increase in stock traded (STRADED) increases LGDPPC by more than $0.03 \%$. But a $1 \%$ increase in inflation decreases LGDPPC by $0.02 \%$. Same is the case with TRADE which shows that a $1 \%$ increase in TRADE causes LGDPPC to decrease by $0.12 \%$. The effect of FDI on GDP is positive as it shows a $1 \%$ increase in FDI causes GDP to increase by $0.02 \%$. Similarly, the FMOLS results of middle income group show that there is a positive relationship between financial and real economy variables, though the sign of each co-efficient differ according to the hypothesized relationship. Except inflation, the sign of all coefficients, exhibit the positive relationship with economic growth. Barring FDI, all variables have the expected sign and are statistically significant at $5 \%$ level or better. The results of middle income group indicate that a $1 \%$ increase in banking index increases LGDPPC by more than $0.21 \%$; a $1 \%$ increase in STRADED increases GDP by more than $0.09 \%$. Savings emerges as the strongest driver of economic growth as a $1 \%$ increase in gross domestic saving GDS increases LGDPPC by $0.32 \%$.

Table 3. FMOLS results

\begin{tabular}{llllll}
\hline Low income & \multicolumn{5}{l}{} \\
\hline LBDI & STRADED & GDS & INF & FDI & TRADE \\
0.1983 & 0.0388 & 0.1293 & -0.0213 & 0.0221 & -0.1295 \\
{$\left[7.2788^{*}\right]$} & {$\left[8.9887^{*}\right]$} & {$[4.4544 *]$} & {$[-0.3065]$} & {$[4.7804 *]$} & {$\left[-3.8531^{*}\right]$} \\
\hline Middle income & & & & & \\
\hline 0.2137 & 0.0959 & 0.3229 & -0.0913 & 0.1813 & 0.0746 \\
{$\left[13.8292^{*}\right]$} & {$\left[8.8479^{*}\right]$} & {$\left[7.9825^{*}\right]$} & {$\left[-9.0203^{*}\right]$} & {$[1.2182]$} & {$\left[6.0158^{*}\right]$} \\
\hline High income-OECD & & & & \\
\hline LBDI & LSMDI & GDS & INF & FDI & TRADE \\
0.2171 & 0.1235 & 0.0284 & -0.0137 & -0.0086 & 0.1230 \\
{$[33.2872 *]$} & {$[8.0742 *]$} & {$\left[9.0201^{*}\right]$} & {$\left[-5.5712^{*}\right]$} & {$[-1.1742]$} & {$[16.3102 *]$} \\
\hline Non-OECD & & & & & \\
\hline 0.0698 & 0.0874 & 0.0870 & 0.0379 & 0.0466 & 0.1880 \\
{$[1.5803 *]$} & {$\left[8.1965^{*}\right]$} & {$[0.7304]$} & {$\left[4.3395^{*}\right]$} & {$[0.8707]$} & {$\left[9.7876^{*}\right]$} \\
\hline
\end{tabular}

Notes: The number of lag truncations used in calculation is 2 . The values in parentheses denote the t-statistics following a standard normal distribution. Asterisk * indicates statistical significance at $5 \%$ critical value.

The impact of inflation (INF) continues to be negative on economic growth. The results indicate that a $1 \%$ increase in inflation decreases LGDPPC by $0.09 \%$. The impact of FDI is also positive and significantly increases the LGDPPC by $0.18 \%$ for a $1 \%$ increase but it's not significantly impacting the LGDPPC. However, the results of FDI must be interpreted with caution. Large standard errors caused by high variability in FDI flows across middle income sample as well as for a given country across different time periods, cause the t-statistics to be significant only at $20 \%$ level despite a large observable co-efficient. A $1 \%$ increase in trade increases LGDPPC by more than $0.07 \%$. The FMOLS results of high income-OECD group show that except inflation and FDI, the coefficient of all study variables are positively impacting the economic growth. Barring FDI, all variables are statistically significant at $5 \%$ level or better. The coefficients show that a $1 \%$ increase in LBDI, LSMI, GDS and TRADE increases the economic growth (LGDPPC) by $0.21 \%, 0.12 \%, 0.02 \%$ and $0.12 \%$, respectively. But coefficients of inflation and FDI decrease economic growth (LGDPPC) by $0.01 \%$ and $0.008 \%$, respectively. The FMOLS results of high income non-OECD group (in which most of the economies are having higher income compared to high income OECD group) indicate that all variables are positively impacting the economic growth and coefficients of LBDI, LSMDI and TRADE are statistically significant at $5 \%$ level or better. INF variable is significant at $10 \%$, whereas, coefficient of FDI is insignificant. The long-run impact of all variables show that a $1 \%$ increase in LBDI, LSMDI, GDS, INF, FDI and TRADE increase the economic growth (LGDPPC) by $0.06 \%$, $0.08 \%, 0.08 \%, 0.03 \%, 0.04 \%$ and $0.18 \%$, respectively. 


\subsection{MWALD Causality Test Results}

After this, we test for causal relationship among study variables of four income groups. The MWALD based Granger causality results presented in Table 4 clearly indicates that in low income group there is bilateral causality between LBDI and LGDPPC ( $\chi^{2}$ - statistics is statistically significant at the $5 \%$ level). But there exists a unidirectional causality running from LGDPPC to STRADED. The estimation results suggest a bi-directional causality between GDS and LGDPPC as well as between INF and LGDPPC. TRADE causes LGDPPC and there is a weak causal relationship between GDP and TRADE. But there is one-way causal relationship between FDI and LGDPPC running from LGDPPC to FDI. The Granger causality results of middle income group clearly suggest a bi-directional causality between LBDI to LGDPPC as well as between STRADED and LGDPPC. GDS and LGDPPC show unidirectional causal relationship running from GDS to LGDPPC but opposite is not true. However, INF and LGDPPC show unidirectional causal relationship running from LGDPPC to INF but the inverse is not true. The causality results further reveal a bi-directional causal relationship between FDI and LGDPPC and between TRADE and LGDPPC. The causality results are appealing because it substantiates the estimated results of FMOLS. However, the causality results of high income-OECD group show that there is a bilateral relationship between LBDI and LGDPPC as well as between LGDPPC and LSMDI. The causal direction between GDS and GDPPC is bilateral but the direction of causal relationship is found stronger from LGDPPC to GDS. The causality results also reveal a bilateral causal relationship between INF and LGDPPC as well as between TRADE and LGDPPC. Finally, there is bilateral and very strong casual relationship between LGDPPC and FDI. The causality results of high income non-OECD income group suggest a bilateral causality between LBDI and LGDPPC. Whereas, LSMDI and LGDPPC reveal a uni-directional causal relationship and in this case stock market causes the economic growth. Similarly, there is one way causal relationship between GDS and LGDPPC running from GDS to LGDPPC. In case of INF and LGDPPC, the causality results also suggest bilateral causal relationship between INF and LGDPPC. While, there is one-way causality running from Trade to LGDPPC but opposite is not true. But the causal relationship between LGDPPC and FDI shows that there exists very weak causal (statistically significant at more than 15 percent level) relationship running from FDI to LGDPPC.

Table 4. The Results of MWALD causality tests

\begin{tabular}{|c|c|c|c|c|c|c|c|c|}
\hline \multirow{2}{*}{ Dependent Variable } & \multicolumn{2}{|l|}{$\begin{array}{l}\text { Low-income } \\
\text { group }\end{array}$} & \multicolumn{2}{|c|}{$\begin{array}{l}\text { Middle } \\
\text { income group }\end{array}$} & \multicolumn{2}{|c|}{$\begin{array}{l}\text { High income } \\
\text { group }\end{array}$} & \multirow{2}{*}{$\begin{array}{l}\text { Non-OECD } \\
\text { group } \\
\chi^{2}- \\
\text { statistics } \\
\end{array}$} & \multirow{2}{*}{$\begin{array}{r}\text { income } \\
\text { p-values } \\
\end{array}$} \\
\hline & $\underline{\chi^{2} \text {-statistics }}$ & p-values & $\begin{array}{l}\chi^{2}- \\
\text { statistics }\end{array}$ & p-values & $\begin{array}{l}\chi^{2}- \\
\text { statistics }\end{array}$ & p-values & & \\
\hline LBDI $\not>$ LGDPPC & $9.4010^{*}$ & 0.0091 & $7.6566 * *$ & 0.0508 & $22.4480 *$ & 0.0001 & $8.4869 *$ & 0.0144 \\
\hline GDPPC $\not A$ LBDI & $23.4664 *$ & 0.0000 & $7.8606^{*}$ & 0.0490 & $7.8329 *$ & 0.0496 & $12.4406^{*}$ & 0.0020 \\
\hline STRADED $\Rightarrow$ A LGDPPC & 0.3145 & 0.8545 & 1.3544 & 0.7163 & -- & -- & -- & -- \\
\hline LGDPPC $\not \mathcal{A}$ STRADED & $3.6667 *$ & 0.1346 & $3.4400 * *$ & 0.1862 & -- & -- & -- & -- \\
\hline LSMDI $\not>$ GDPPC & -- & -- & -- & -- & $45.6766^{*}$ & 0.0000 & $11.9266^{*}$ & 0.0026 \\
\hline LGDPPC L $\not>$ SMDI & -- & -- & -- & -- & $6.4583 * *$ & 0.0913 & 2.8019 & 0.2464 \\
\hline GDS $\not=$ LGDPPC & $6.1017 *$ & 0.0473 & $14.6017^{*}$ & 0.0022 & $4.4455^{* *}$ & 0.2172 & $6.1546^{*}$ & 0.0461 \\
\hline LGDPPC $\not>$ GDS & $7.0446^{*}$ & 0.0295 & 2.1390 & 0.5441 & $10.8805^{*}$ & 0.0124 & 0.2215 & 0.8952 \\
\hline INF $\not A$ LGDPPC & $3.1048^{* *}$ & 0.2117 & 0.5693 & 0.9034 & $7.6872 *$ & 0.0529 & $6.3970 * *$ & 0.0406 \\
\hline LGDPPC $\not A$ INF & $6.4217^{*}$ & 0.0403 & $6.9117 * *$ & 0.1784 & $4.8547 * *$ & 0.1476 & $5.2511^{* *}$ & 0.0368 \\
\hline TRADE $\Rightarrow$ LGDPPC & $3.8430 * *$ & 0.1464 & $7.0592 * *$ & 0.0602 & $6.6724 * *$ & 0.0831 & $4.7359 * *$ & 0.0937 \\
\hline LGDPPC $\not A$ TRADE & 2.5943 & 0.2733 & $8.0048 *$ & 0.0459 & $9.9388^{*}$ & 0.0161 & 2.1714 & 0.3377 \\
\hline FDI $\not A$ LGDPPC & 0.2968 & 0.8621 & $4.6736^{* *}$ & 0.1973 & $26.4807^{*}$ & 0.0000 & 1.9348 & 0.3801 \\
\hline LGDPPC $\Rightarrow$ FDI & $7.9799 *$ & 0.0185 & $3.9443 * *$ & 0.2675 & $12.8831^{*}$ & 0.0049 & 0.8002 & 0.6703 \\
\hline
\end{tabular}

\footnotetext{
Note: $7 \mathbf{A}$ shows null hypothesis does not Granger Cause and the values in parentheses are probabilities.

* indicates significant at $5 \%$ and less critical value.

** indicates significant at $10 \%$ and more critical value.
}

\subsection{Variance Decomposition (VAR based) Test Results}

After analysing the causality results, we turn to VAR analysis for income groups. The forecast error variance decompositions of LGDPPC in VAR are presented in Table 5. The main role of variance decomposition is to 
separate the variation in an endogenous variable into the component shocks to the VAR and provides information about the relative importance of each random residual in affecting the variables in the VAR. It is typical in VAR analysis that a variable explains a huge proportion of its forecast error variance, which is the case in our analysis of growth variation, which explains the biggest part of itself across all income groups. The columns provide the percentage of the forecast error variance due to each innovation in VAR framework, with each row adding up to 100 .

Table 5. Variance decomposition results

\begin{tabular}{|c|c|c|c|c|c|c|c|}
\hline Period & LGDPPC & LBDI & STRADED & GDS & INF & TRADE & FDI \\
\hline \multicolumn{8}{|c|}{ Low income } \\
\hline 1 & 100 & 0.00 & 0.00 & 0.00 & 0.00 & 0.00 & 0.00 \\
\hline 2 & 97.75 & 0.86 & 0.02 & 0.83 & 0.16 & 0.38 & 0.01 \\
\hline 4 & 92.52 & 4.69 & 0.24 & 1.01 & 0.34 & 1.16 & 0.04 \\
\hline 6 & 88.20 & 7.69 & 0.24 & 2.19 & 0.56 & 1.08 & 0.05 \\
\hline 8 & 79.76 & 11.18 & 0.23 & 4.90 & 2.89 & 0.91 & 0.13 \\
\hline 10 & 64.97 & 12.35 & 0.46 & 15.03 & 6.42 & 0.63 & 0.14 \\
\hline \multicolumn{8}{|c|}{ Middle income } \\
\hline 1 & 100 & 0.00 & 0.00 & 0.00 & 0.00 & 0.00 & 0.00 \\
\hline 2 & 99.04 & 0.00 & 0.13 & 0.29 & 0.02 & 0.51 & 0.00 \\
\hline 4 & 95.64 & 0.02 & 0.62 & 1.70 & 0.04 & 1.98 & 0.00 \\
\hline 6 & 91.87 & 0.03 & 1.11 & 3.79 & 0.06 & 3.14 & 0.00 \\
\hline 8 & 88.23 & 0.03 & 1.51 & 6.30 & 0.07 & 3.86 & 0.00 \\
\hline 10 & 84.76 & 0.03 & 1.80 & 9.05 & 0.08 & 4.27 & 0.00 \\
\hline \multicolumn{8}{|c|}{ High income-OECD } \\
\hline Period & LGDPPC & LBDI & LSMDI & GDS & INF & TRADE & FDI \\
\hline 1 & 100 & 0.00 & 0.00 & 0.00 & 0.00 & 0.00 & 0.00 \\
\hline 2 & 95.80 & 0.75 & 2.73 & 0.14 & 0.29 & 0.26 & 0.03 \\
\hline 4 & 91.29 & 1.30 & 5.29 & 0.32 & 1.20 & 0.56 & 0.02 \\
\hline 6 & 89.38 & 2.11 & 5.07 & 0.36 & 2.17 & 0.90 & 0.02 \\
\hline 8 & 88.15 & 3.04 & 4.27 & 0.32 & 2.97 & 1.24 & 0.01 \\
\hline 10 & 87.08 & 3.97 & 3.54 & 0.26 & 3.56 & 1.58 & 0.01 \\
\hline \multicolumn{8}{|c|}{ Non-OECD } \\
\hline 1 & 100 & 0.00 & 0.00 & 0.00 & 0.00 & 0.00 & 0.00 \\
\hline 2 & 94.23 & 0.26 & 3.93 & 0.33 & 0.04 & 0.64 & 0.56 \\
\hline 4 & 81.44 & 1.87 & 8.46 & 2.01 & 0.60 & 2.30 & 3.32 \\
\hline 6 & 74.0 & 2.70 & 9.10 & 4.28 & 2.03 & 3.49 & 4.40 \\
\hline 8 & 68.61 & 3.08 & 8.70 & 6.31 & 3.74 & 4.75 & 4.80 \\
\hline 10 & 64.16 & 3.27 & 8.11 & 7.89 & 5.34 & 6.17 & 5.06 \\
\hline
\end{tabular}

For low income group, the LGDPPC forecast error variance decomposition shows that more than $64 \%$ after ten time period horizon is explained by its own innovations and rest is explained by innovations of other explanatory variables. Among those, share of GDS is highest (15.03\%) followed by LSMDI $(12.35 \%)$ and then INF is $(6.42 \%)$, respectively. The shares of STRADED, TRADE and FDI are very low. The GDPPC forecast error variance decomposition of middle income group is significant and more than $84 \%$ are explained by its own innovations and only about $16 \%$ is explained by the innovation of other explanatory variables. Among all explanatory variables, more than $9.05 \%$ of total variance is explained by GDS followed by FDI $(4.27 \%)$ and STRADED (1.80\%) respectively. Similarly, the forecast-error variance of GDPPC of high income-OECD group depict that the GDPPC innovations are explained itself by more than $87 \%$. Rest is explained by the error variance of LBDI (3.97), LSMDI (3.54), INF (3.56) and TRADE (1.58), respectively. The High income non-OECD group results reveal that the forecast-error variance of GDPPC up to ten periods is explained $64 \%$ by its own innovations and rest by other explanatory variables. Among all study variables, the share of LSMDI is highest $8.11 \%$, followed by GDS (7.89\%), TRADE (6.17\%), Inflation (5.37\%), FDI (5.06\%) and LBDI (3.27\%) respectively. This shows that in case of high income NON-OECD countries, the roles of financial variables are more than $20 \%$ compared to $16 \%$ by real economic variables. This implies that the role of financial development is prominent compared to real economic variables. 


\section{Conclusion and Policy Implications}

The study results conclude that there is a long-run relationship between financial development and economic growth for all income groups. Based on the estimated results, the major findings of the study are as follows: Banking and economic growth exhibit strong bilateral causality for all income groups. This implies that while banking development drives economic growth, greater amount of banking services are also required at higher levels of development. Gross domestic savings is another important driver of economic growth for low and middle income group countries and plays a less significant role for high income groups. Economic growth causes stock market development for low income countries, stock market system and economic growth reinforce each other for middle and high income-OECD countries, while stock market drives economic growth for high income non-OECD countries. FDI is an important determinant of economic growth for low and middle income countries which is replaced by trade in case of middle and high income-OECD countries. Inflation hurts economies across income groups except in case of high income non-OECD group, which comprises of many oil exporting nations. Where rise in oil prices implies input-inflation for rest of the world, it results in higher export earning and growth for these oil exporting countries. From variance decomposition results, it may be noted that the proposed finance and economic variables explain $36 \%$ and $46 \%$ of variations in economic growth for low and high income Non-OECD group respectively. This implies that the role of financial development and policy interventions shall be higher in these economies. In contrast, the financial and economic variables explain merely $13 \%$ and $16 \%$ of variations in economic growth for middle and high income OECD income groups. The lesser role of innovations in explaining economic growth implies that one must look for additional economic variables that may drive economic growth. In their absence, time-series analysis of data seems to be more reliable and the role of financial development and other policy variable is relatively marginal. The important policy implications for countries belonging to different income groups are as follows:

a). Low income group: banking is the strongest driver of economic growth and hence the focus shall be on development of banking sector through institutional set-up, branch expansion, product innovation, better services, use of ICTs tools and a more comprehensive regulatory and governance framework. Governments need to encourage savings by providing alternative investment channels, increased monetization, fiscal incentives, strengthening pension sector and interest rate, interest rate liberalization and augmentation of financial deepening process. Stock markets are not the determinant of economic growth. On the contrary, economic development propels stock market development. In other words, stock market is not a critical policy variable for accelerating economic growth and hence its role in most such economies has been over-emphasized. FDI inflows should be encouraged through regulatory and fiscal response while inflation should be curtailed by managing supply side bottlenecks.

b). Middle income group: banking and GDS continue to be important drivers of economic growth and hence need policy support. Of course, banking development and savings growth reinforce each other. Stock market development is a driver of economic growth though it is not as significant as other financial variables such as banking and savings. The government should make an active effort to develop a competitive stock market system that encourages product innovation, provides services at lower costs by improving efficiency and using network economies as well as promotes investor education and activism leading to greater financial inclusion. FDI needs to be strongly encouraged while inflation needs to be kept under control through relevant policy measures.

c). High income-OECD group: stock market is the strongest driver of economic growth closely followed by banking and savings. Trade emerges as the strong determinant of economic growth while the role of FDI is virtually insignificant. This is understandable as the sample countries account for large part of international trade. They also account for large FDI outflows which are tapped by low and middle income countries. Such regimes need to support trade through institutional and fiscal measures, multi-lateral trade agreements, developing transporting networks and pursuing an active export-import polices.

d). High income Non-OECD group: trade is the strongest driver of economic growth and needs to be supported through policy measures. Stock market and savings are critical for economic development followed by banking. The regimes must invest in developing capital market active system through policy and regulatory support, encourage savings and deepen banking practices. Inflation management is not as critical as it does not hurt economic growth.

To conclude, we can say that the findings of this study are in agreement with (Levine \& Zervos, 1998; Levine et al., 2000; Hassan et al., 2011) on the role of financial development and economic growth. Causality results are consistent with Shan, Morris, and Sun (2001) and (Demetriades and Hussein, 1996; Blackburn and Hung, 1998; 
Khan, 2001), but contrary to (Christopoulos and Tsionas, 2004). The study results of stock market development and its causal relationship with economic growth are inline with (see for example, Levine and Zervos,1998; Levine et al., 2000). The outcomes on the role of macroeconomic variables are consistent with the study of (Gries et al., 2009) and (Hassan et al., 2011). Our research contributes to both financial development as well as economic policy literature. The findings are relevant for academicians', policy makers and financial market players. However, results with regard to low income countries must be interpreted with caution as due to paucity of data low and lower middle income countries were merged. Hence the policy recommendations for the low income group may need some review in light of individual country data relating to their economic settings and financial development.

\section{Acknowledgments}

The authors would like to thank Professor Muneesh Kumar, Mr. Raghunathan, Dr. Ritesh Kumar Mishra and Md. Zulquar Nain for their helpful comments and suggestions on earlier drafts. All errors are ours.

\section{References}

Al-Awad, M., \& Harb, N. (2005). Financial development and economic growth in the Middle East. Applied Financial Economics, 15, 1041-1051. http://dx.doi.org/10.1080/09603100500120639

Ang, B. J. (2008). A survey of recent developments in the literature of finance and growth. Journal of Economic Surveys, 22(3), 536-576. http://dx.doi.org/10.1111/j.1467-6419.2007.00542.x

Arestis, P., Demetriades, O. P., \& Luintel, K. B. (2001). Financial development and economic growth: The role of stock markets. Journal of Money, Credit and Banking, 33(1), 16-41. http://dx.doi.org/10.2307/2673870

Atje, R., \& Jovanovic, B. (1993). Stock markets and development. European Economic Review, 37(2-3), 632-640. http://dx.doi.org/10.1016/0014-2921(93)90053-D

Beck, T., Levine, R., \& Loayza, N. (2000). Finance and the sources of growth. Journal of Financial Economics, 58(1-2), 261-300. http://dx.doi.org/10.1016/S0304-405X(00)00072-6

Blackburn, K., \& Hung, T. Y. (1998). A theory of growth, financial development and trade. Economica, 65(257), 107-124. http://dx.doi.org/10.1111/1468-0335.00116

Calderon, C., \& Liu, L. (2003). The direction of causality between financial development and economic growth. Journal of Development Economics, 72, 321-334. http://dx.doi.org/10.1016/S0304-3878(03)00079-8

Cameron, R., Olga, C., Hugh, T. P., \& Richard, T. (1967). Banking in the Early Stages of Industrialization: A Study in Comparative Economic History. New York: Oxford University Press.

Caporale, G. M., Christophe, R., Robert, S., \& Anamaria, S. (2009). Financial Development and Economic Growth: Evidence from Ten New EU Members. DIW Berlin Discussion Paper 940 .

Christopoulos, D., \& Tsionas, E. (2004). Financial development and economic growth: evidence from panel unit root and cointegration tests. Journal of Development Economics, 73(1), 55-74. http://dx.doi.org/10.1016/j.jdeveco.2003.03.002

Chuah, H., \& Thai, W. (2004). Financial development and economic growth: Evidence from causality tests for the GCC countries. IMF Working Paper .

Claessens, S., \& Laeven, L. (2005). Financial dependence, banking sector competition and economic growth. Journal of the European Economic Association, 3(1), 179-207. http://dx.doi.org/10.1162/1542476053295322

Cole, R. A., Moshirian, F., \& Wu, Q. (2008). Bank stock returns and economic growth. Journal of Banking \& Finance, 995-1007. http://dx.doi.org/10.1016/j.jbankfin.2007.07.006

Cooray, A. (2010). Do stock markets lead to economic growth? Journal of Policy Modeling, 32(4), 448-460. http://dx.doi.org/10.1016/j.jpolmod.2010.05.001

Deidda, G. (2006). Interaction between economic and financialdevelopment. Journal of Monetary Economics, 53(2), 233-248. http://dx.doi.org/10.1016/j.jmoneco.2005.03.007

Demetriades, P., \& Hussein, K. (1996). Does financial development cause economic growth? Time series evidence from 16 countries. Journal of Development Economics, 51(2), 387-411. http://dx.doi.org/10.1016/S0304-3878(96)00421-X

Enisan, A. A., \& Olufisayo, O. A. (2009). Stock market development and economic growth: Evidence from seven sub-Sahara African countries. Journal of Economics and Business, 61(2), 162-171. http://dx.doi.org/10.1016/j.jeconbus.2008.05.001 
Goldsmith, R. (1969). Financial Structure and Development. New Haven, CT: Yale University Press.

Gregorio, J. D., \& Guidotti, E. P. (1995). Financial development and economic growth. World Development, 23(3), 433-448. http://dx.doi.org/10.1016/0305-750X(94)00132-I

Gries, T., Kraft, M., \& Meierrieks, D. (2009). Linkages between financial deepening, trade openness, and economic development: Causality evidence from Sub-saharan africa. World Development, 37(12), 1849-1860. http://dx.doi.org/10.1016/j.worlddev.2009.05.008

Gurley, J., \& Shaw, E. (1967). Financial structure and economic development. Economic Development and Cultural Change, 15(3), 257-268. http://dx.doi.org/10.1086/450226

Harris, D. R. (1997). Stockmarkets and development: A re-assessment. European Economic Review, 41(1), 139-146. http://dx.doi.org/10.1016/S0014-2921(96)00021-9

Hassan, K. M., Sanchez, B., \& Yu, J. S. (2011). Financial development and economic growth: New evidence from panel data. The Quarterly Review of Economics and Finance, 51(1), 88-104. http://dx.doi.org/10.1016/j.qref.2010.09.001

Hong, C. L., \& Thai, V. C. (2004). Financial development and economic growth: Evidence from causality tests for the GCC countries. IMF Working Paper, 1-41.

Iyare, S., \& Moore, W. (2011). Financial sector development and growth in small open economies. Applied Economics, 43(10), 1289-1297. http://dx.doi.org/10.1080/00036840802600350

Keynes, J. (1936). The General Theory of Employment, Interest and Money. London: Macmillan.

Khan, A. (2001). Financial development and economic growth. Macroeconomic Dynamics, 15, 413-433.

Khan, S. M., \& Senhadji, S. A. (2003). Financial development and economic growth: A review and new evidence. Journal of African Economies, 12(2), 89-100. http://dx.doi.org/10.1093/jae/12.suppl_2.ii89

Kindleberger, C. (1978). Manias, Panics and Crashes. New York: Basic Books.

King, R., \& Levine, R. (1993a). Finance and growth: Schumpeter might be right. Quarterly Journal of Economics, 108, 717-737. http://dx.doi.org/10.2307/2118406

King, R., \& Levine, R. (1993b). Finance, entrepreneurship, and growth: theory and evidence. Journal of Monetary Economics, 32, 513-542. http://dx.doi.org/10.1016/0304-3932(93)90028-E

Levine, R. (1997). Financial development and economic growth. Journal of Economic Literature, 35(2), 688-726.

Levine, R., \& Zervos, S. (1998). Stock markets, banks and economic growth. American Economic Review, 88(3), 537-558.

Levine, R., Loayza, N., \& Thorsten, B. (2000). Financial intermediation and growth: Causality and causes. Journal of Monetary Economics, 46(1), 31-77. http://dx.doi.org/10.1016/S0304-3932(00)00017-9

Levine, R. (2005). Finance and growth: theory and evidence. In H. o. In P. Aghion and S. Durlauf (eds), Handbook of Economic Growth (pp. 865-934). Amsterdam: Elsevier Science. http://dx.doi.org/10.1016/S1574-0684(05)01012-9

Lucas, R. E. (1988). On the mechanics of economic development. Journal of Monetary Economics, 22(1), 3-42.

Luintel, B. K., \& Khan, M. (1999). Aquantitativereassessment of the finance-growthnexus: evidence from a multivariate VAR. Journal of Development Economics, 60, 381-405. http://dx.doi.org/10.1016/S0304-3878(99)00045-0

Mankiw, G. N., Romer, D., \& Weil, N. D. (1992). A contribution to the empirics of growth. The Quarterly Journal of Economics, 107(2), 407-437. http://dx.doi.org/10.2307/2118477

McKinnon, R. (1973). Money and Capital in Economic Development. Washington, DC: Brookings Institution.

Patrick, H., \& Yung, C. (1994). The financial development of Japan, Korea, and Taiwan: Growth, repression, and liberalization. New York: Oxford University Press.

Pedroni, P. (1999). Critical Values for Cointegration Tests in Heterogeneous Panels with Multiple Regressors. Oxford Bulletin of Economics and Statistics, 61(0), 653-670. http://dx.doi.org/10.1111/1468-0084.61.s1.14

Pedroni, P. (2000). Fully modified OLS for Heterogeneous Co-integrated panels. Advances in Econometrics, 15, 93-130. http://dx.doi.org/10.1016/S0731-9053(00)15004-2

Pedroni, P. (2001). Purchasing power parity tests in Co-integrated panels. Review of Economics and Statistics, 83, 


\section{7-731. http://dx.doi.org/10.1162/003465301753237803}

Pedroni, P. (2004). Panel cointegration: Asymptotic and finite sample properties of pooled time-series tests with application to the PPP hypothesis. Econometric Theory, 20(03), 597-625. http://dx.doi.org/10.1016/S0731-9053(00)15004-2

Pittis, N. (1999). Efficient Estimation Of Cointegrating Vectors and Testing for Causality in Vector Autoregressions. Journal of Economic Surveys, 13(1), 1-35. http://dx.doi.org/10.1111/1467-6419.00073

Rajan, R., \& Zingales, L. (1998). Financial dependence and growth. American Economic Review, 88(3), 559-586.

Rousseaua, P., \& Wachtel, P. (2000). Equity markets and growth: Cross-country evidence on timing and outcomes, 1980-1995. Journal of Banking \& Finance, 24(12), 1933-1957. http://dx.doi.org/10.1016/S0378-4266(99)00123-5

Shan, J., Morris, A., \& Sun, F. (2001). Financial development and economic growth: An egg-chicken problem? Review of International Economics, 9, 443-454. http://dx.doi.org/10.1111/1467-9396.00291

Singh, A. (1997). Financial liberalisation, stock markets and economic development. The Economic Journal, 107(442), 771-782. http://dx.doi.org/10.1111/j.1468-0297.1997.tb00042.x

Stiglitz, J. (1994). The role of the state in financial markets. In M. Bruno and B. Pleskovic (Eds), Proceedings of the World Bank Annual Conference on Development Economics, 1993: Supplement to The World Bank Economic Review and The World Bank Research. Washigton, DC.

Toda, H. Y., \& Yamamoto, T. (1995). Statistical inference in vector autoregressions with possibly integrated processes. Journal of Econometrics, 225-250. http://dx.doi.org/10.1016/0304-4076(94)01616-8

Wu, L., Han, H., \& Su-Yin, C. (2010). The dynamic impacts of financial institutions on economic growth: Evidence from the European Union. Journal of Macroeconomics, 32, 879-891. http://dx.doi.org/10.1016/j.jmacro.2009.09.003

\section{Notes}

Note 1. Lucas (1988) emphasized on the downside risk of financial sector in economic growth and asserted against the over-stressed role of financial sector in economic growth.

Note 2. Levine (2005) provides valid arguments regarding use of fixed effect in cross country analysis.

Note 3. See recent study by Ang (2008) and citations therein for additional studies on the recent developments in the literature of finance and growth.

Note 4. The income based group-wise classification of World Bank is based upon 2008 GNI per capita. The groups are: Low income, $\$ 975$ per capita or less; Lower and middle income, $\$ 976-\$ 3,855$ per capita; Upper middle income, $\$ 3,856-\$ 11,905$ per capita; and High income, $\$ 11,906$ per capita or more.

Note 5. The list of sample countries is shown in Table 7 (Appendix).

Note 6. In appendix-A, Table 1, 2,3,4,5 and 6 show estimated principle component vectors.

Note 7. In order to conserve the space we have avoided mentioning the unit root results. However, the results are available upon request.

\section{Appendix}

Appendix 1. Principle component analysis for LBDI: Low income group

\begin{tabular}{llll}
\hline & PCA1 & PCA2 & PCA3 \\
\hline Eigen values & 2.6037 & 0.2954 & 0.1010 \\
\% of variance & 0.8679 & 0.0985 & 0.0337 \\
Cumulative \% & 0.8679 & 0.9663 & 1.0000 \\
\hline Variable & Vector1 & Vector 2 & Vector 3 \\
\hline DMCPS & 0.5561 & 0.8023 & 0.2172 \\
DCPBS & 0.5967 & -0.2035 & -0.7763 \\
BM & 0.5786 & -0.5612 & 0.5918 \\
\hline
\end{tabular}


Appendix 2. Principle component analysis for LBDI: Middle income group

\begin{tabular}{llll}
\hline & PCA1 & PCA2 & PCA3 \\
\hline Eigen values & 2.6517 & 0.2643 & 0.0840 \\
\% of variance & 0.8839 & 0.0881 & 0.0280 \\
Cumulative \% & 0.8839 & 0.9720 & 1.0000 \\
\hline Variable & Vector1 & Vector 2 & Vector 3 \\
\hline DMCPS & 0.5922 & -0.2944 & -0.7501 \\
DCPBS & 0.5832 & -0.4857 & 0.6511 \\
BM & 0.5560 & 0.8230 & 0.1159 \\
\hline
\end{tabular}

Appendix 3. Principle component analysis for LBDI: High income-OECD group

\begin{tabular}{llll}
\hline & PCA1 & PCA2 & PCA3 \\
\hline Eigen values & 2.1496 & 0.7728 & 0.0776 \\
\% of variance & 0.7165 & 0.2576 & 0.0259 \\
Cumulative \% & 0.7165 & 0.9741 & 1.0000 \\
\hline Variable & Vector1 & Vector 2 & Vector 3 \\
\hline DMCPS & 0.4070 & 0.9128 & 0.0339 \\
DCPBS & 0.6422 & -0.3123 & 0.7000 \\
BM & 0.6496 & -0.2631 & -0.7133 \\
\hline
\end{tabular}

Appendix 4. Principle component analysis for LBDI: Non-OECD income group

\begin{tabular}{llll}
\hline & PCA1 & PCA2 & PCA3 \\
\hline Eigen values & 2.7339 & 0.2253 & 0.0408 \\
\% of variance & 0.9113 & 0.0751 & 0.0136 \\
Cumulative \% & 0.9113 & 0.9864 & 1.0000 \\
\hline Variable & Vector 1 & Vector 2 & Vector 3 \\
\hline DMCPS & 0.5836 & -0.4767 & 0.6574 \\
DCPBS & 0.5914 & -0.3052 & -0.7464 \\
BM & 0.5564 & 0.8244 & 0.1039 \\
\hline
\end{tabular}

Appendix 5. Principle component analysis for LSMDI: High income-OECD group

\begin{tabular}{lccc}
\hline & PCA1 & PCA2 & PCA3 \\
\hline Eigen values & 1.9812 & 0.7194 & 0.2994 \\
\% of variance & 0.6604 & 0.2398 & 0.0998 \\
Cumulative \% & 0.6604 & 0.9002 & 1.0000 \\
\hline Variable & Vector1 & Vector 2 & Vector 3 \\
\hline STRADED & 0.6374 & -0.2030 & -0.7433 \\
MARCAP & 0.6004 & -0.4737 & 0.6443 \\
LCOMP & 0.4829 & 0.8570 & 0.1801 \\
\hline
\end{tabular}


Appendix 6. Principle component analysis for LSMDI: Non-OECD income group

\begin{tabular}{lccc}
\hline & PCA1 & PCA2 & PCA3 \\
\hline Eigen values & 2.3873 & 0.4512 & 0.1615 \\
$\%$ of variance & 0.7958 & 0.1504 & 0.0538 \\
Cumulative \% & 0.7958 & 0.9462 & 1.0000 \\
\hline Variable & Vector1 & Vector 2 & Vector 3 \\
\hline LCOMP & 0.5338 & 0.8395 & 0.1012 \\
MARCAP & 0.6045 & -0.2952 & -0.7399 \\
STRADED & 0.5913 & -0.4562 & 0.6650 \\
\hline
\end{tabular}

Appendix 7. Income group-wise list of sample countries

\begin{tabular}{|c|c|c|c|}
\hline Low income & Middle income & High income OECD & $\begin{array}{l}\text { High } \\
\text { income Non-OECD }\end{array}$ \\
\hline Bangladesh & Argentina & Australia & Barbados \\
\hline Kenya & Brazil & Austria & Cyprus \\
\hline Zimbabwe & Botswana & Belgium & Hong Kong SAR, China \\
\hline Bolivia & Chile & Canada & Oman \\
\hline Egypt, Arab Rep. & China & Switzerland & Saudi Arabia \\
\hline Ghana & Colombia & Czech Republic & Singapore \\
\hline Indonesia & Costa Rica & Germany & Trinidad and Tobago \\
\hline India & Ecuador & Denmark & \\
\hline Sri Lanka & Iran, Islamic Rep. & Spain & \\
\hline Morocco & Jamaica & Estonia & \\
\hline Nigeria & Jordan & Finland & \\
\hline Pakistan & Mexico & France & \\
\hline \multirow[t]{19}{*}{ Philippines } & Mauritius & United Kingdom & \\
\hline & Malaysia & Greece & \\
\hline & Namibia & Hungary & \\
\hline & Panama & Ireland & \\
\hline & Peru & Iceland & \\
\hline & Romania & Israel & \\
\hline & Russian Federation & Italy & \\
\hline & Thailand & Japan & \\
\hline & Tunisia & Korea, Rep. & \\
\hline & Turkey & Luxembourg & \\
\hline & Venezuela, RB & Netherlands & \\
\hline & South Africa & Norway & \\
\hline & & New Zealand & \\
\hline & & Poland & \\
\hline & & Portugal & \\
\hline & & Slovak Republic & \\
\hline & & Slovenia & \\
\hline & & Sweden & \\
\hline & & United States & \\
\hline
\end{tabular}

Note: Low income group consists of three low income countries (Bangladesh, Kenya and Zimbabwe) and rest are from lower middle income countries. 